lonut Bratosin* - Valeriu Gabriel Ghica** - Mircea lonut Petrescu** Mihai Buzatu**** - Alina Daniela Necsulescu $^{* * * *}$ - Gheorghe lacob ${ }^{* * * * * *}$

\title{
Recycling Li-ion batteries in eco-friendly environments
}

\section{INTRODUCTION}

Facilities in the security services, the army, health, transport, energy, public services and many other organizations benefit from the presence of a certain equipment: batteries, which are essential for the functioning of the infrastructure and the economy of society.

We cannot imagine what would happen if the batteries were discharged during the submersion of a submarine. Or, what would happen if the telecommunication systems or the air navigation systems were prevented from working at optimal parameters due to sudden discharges of the batteries they contain? We have listed only few situations in which batteries can affect the critical infrastructure of a country.

When Li-ion batteries are discussed, automatically we think of $\mathrm{LiCoO}_{2} / \mathrm{LCO}$ batteries. But there are five different types of Li-ion batteries, as follows: LiMn $\mathrm{O}_{4} / \mathrm{LMO}$, LiNiMn$\mathrm{CoO}_{2} / \mathrm{NMC}, \mathrm{LiFePO}_{4} / \mathrm{LFP}, \mathrm{LiNiCoAIO} / \mathrm{NCA}_{2}$ and $\mathrm{Li}_{4} \mathrm{Ti}_{5} \mathrm{O}_{12} /$ LTO [1].

LCO batteries have a high specific energy, a quick charging capacity and can be combined with other battery systems in order to improve their characteristics. LMO is defined by a good specific energy, but low performance and life cycle. Batteries only on Li-Mn are not used anymore in the usual applications; the majority of LMO are combined with NMC to increase their specific energy. NMC also has a high specific energy, a low auto-heating rate and a good life cycle. LFP batteries are cells with the following characteristics: low specific energy, high autodischarging capacity, and even if it is charged completely, the battery is very stable. NCA is the battery with the highest specific energy compared with other Li-ion batteries, having a good specific power and high costs. LTO based batteries are characterized by a high life cycle, low specific energy, and the highest cost compared with other systems [1].
Li-ion batteries have their own place in the modern economy: we find them in mobile phones, laptops, tablets, video cameras, etc., and it is hard to imagine a world without them. The LCO, NMC and NCA batteries have the highest specific energy compared with others and a good performance, but not a long life cycle. Each domain in which the battery is used has his own requirements, and even if LTO has a long life cycle compared with LCO, specific energy is far more important for electronic devices.

\section{LI-ION BATTERIES TOMORROW}

The use of Li-ion batteries in the automotive industry presents a new challenge. The electric vehicle (EV) is a transport vehicle which uses an energy source that is either an exclusive electric system or a hybrid electric system. This type of vehicle has zero emission when powered by an electric motor using a battery as power source. Tests have shown that a Tesla car driven in the Midwest (US) produces $226 \mathrm{~g}$ of carbon dioxide $\left(\mathrm{CO}_{2}\right)$ per kilometer over its life cycle. However, if all the manufacturing processes necessary for the production of electricity are taken into account and not only the pollutants eliminated on the exhaust pipe, this quantity of carbon dioxide produced is greater than the total quantity resulting from the traditional models of combustion engines [3]. The manufacturing process of a battery requires large amounts of energy, starting with the exploitation of the raw materials to the energy consumed in production.

The electric vehicles sales registered a growth of $86 \%$ in the past three years due to:

- High demand in China supported by government incentives:

- Launch of the Tesla 3 model, with 250,000 units sold worldwide;

- Diesel crisis in Europe.
ÖSSZEFOGLALÁS: Jelen tanulmány egy olyan kísérlet eredményeit mutatja be, amelynek célja a színesfémek (pl. Co, Li Cu és Al) kinyerése a már elhasználódott, a mobiltelefon-iparban alkalmazott Li-ion akkumulátorokból. Egy optimális eljárás került kifejlesztésre a LiCoO vegyületet tartalmazó aktív paste (elektrolit) elválasztására az alumínium katódtól. Ehhez ultrahangos fürdő́t használtunk, amelyben különböző savas oldatok (pl. citromsav, ecetsav, tejsav) szerepeltek oldóanyagként. Az általunk kidolgozott eljárás a következő előnyökkel rendelkezik: alacsony költségigény, nagyfokú hatékonyság (90\%), környezetbarát.

KULCSSZAVAK: újrahasznosítás, Li-ion akkumulátorok, környezetbarát, ultrahangos fürdó
ABSTRACT: The paper presents the results of a research carried out with the goal of recovering the useful non-ferrous metals (i.e. Co, Li Cu and Al) from spent Li-ion batteries used in the mobile phone industry. An optimal process was developed to separate active paste (containing $\mathrm{LiCOO}_{2}$ compound) from the aluminium cathode. For this purpose, an ultrasonic bath was used, in which different acid solutions (i.e. citric acid, acetic acid, lactic acid) were introduced as a leaching agent. This recovery process presents the following advantages: it has low costs, the process has high recovery efficiency $(90 \%)$, and is largely ecological.

KEY WORDS: recycling; Li-ion batteries; environmental friendly; ultrasound bath

* Phd. Stud. University Politehnica of Bucharest, 313 Spl. Independenței, Bucharest, Romania. ORCID: 0000-0002-4305-6106

** Prof. PhD. Eng. University Politehnica of Bucharest, 313 Spl. Independenței, Bucharest, Romania. Bukaresti Műszaki Egyetem, professzor és doktorandusz. ORCID: 0000-0001-7982-3330

*** Prof. PhD. Eng. University Politehnica of Bucharest, 313 Spl. Independenței, Bucharest, Romania.ORCID: 0000-0003-0144-7077

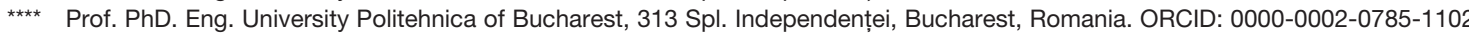

***** Lect. Phd. Eng. University Politehnica of Bucharest, 313 Spl. Independenței, Bucharest, Romania. ORCID: 0000-0002-2837-7286

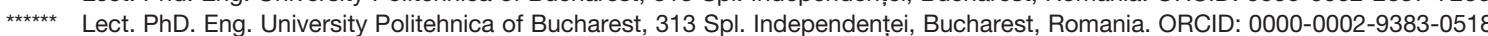




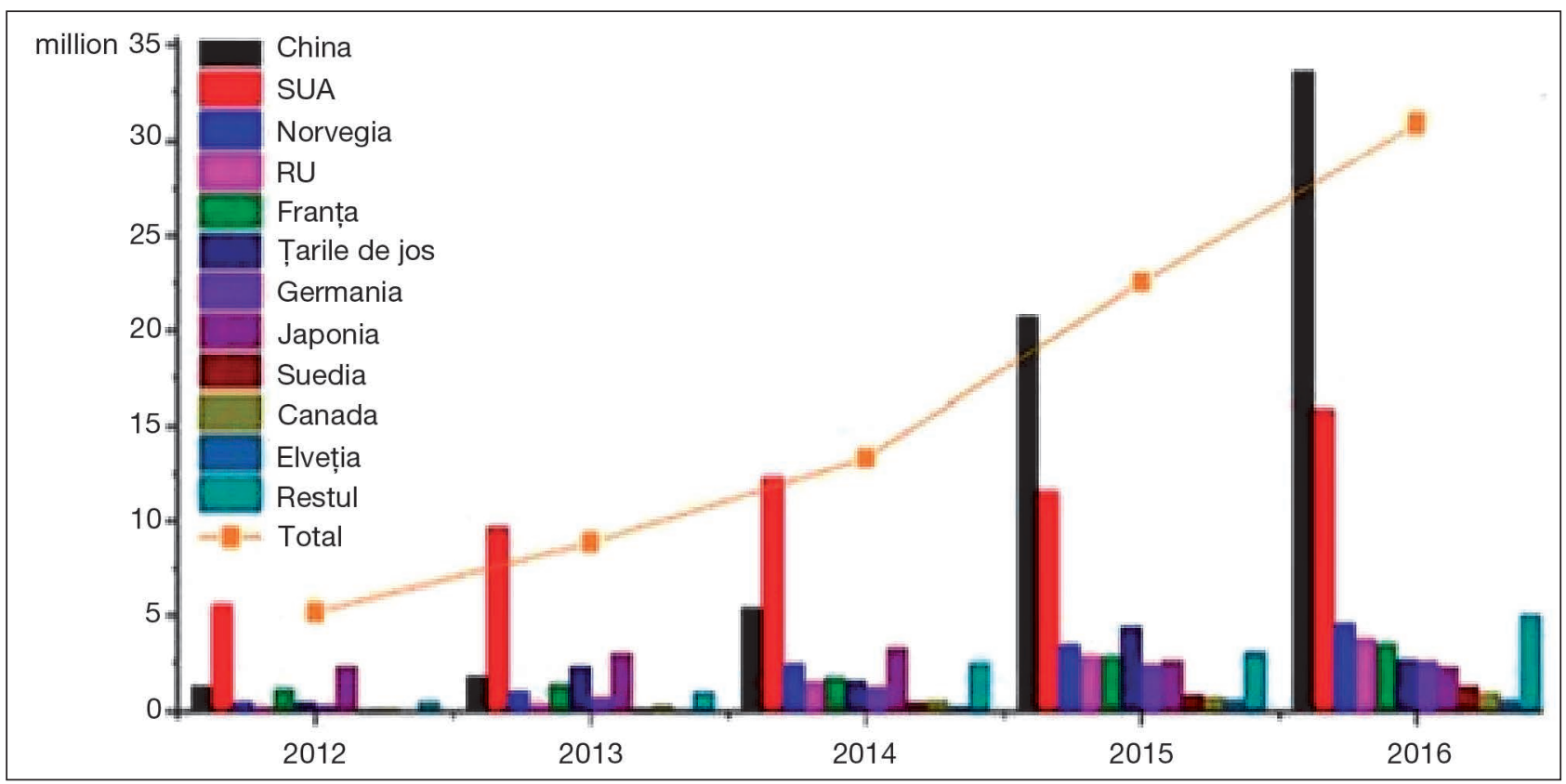

Figure 1. Worldwide registered electric vehicles, 2012-2016 [4]

The market for electric vehicles (Figure 1) is still in its infancy and may ramp up significantly in the coming years. It should not be forgotten that there are still large stocks of unsold electric vehicles.

\section{THE MARKET OF RAW MATERIALS NEEDED FOR ELECTRIC VEHICLES}

Lithium (Li) is one of the most wanted metals nowadays. Lithium-ion batteries store the energy that powers mobile phones, electric cars and grids. By 2025, Li demand is expected to triple. $54 \%$ of the world's Lithium resources can be found in the so-called "Lithium triangle", a region that covers large areas of Chile, Argentina and Bolivia (Figure 2).

Another metal used in the production of Li-ion batteries (more expensive than Lithium) is Cobalt (Co), which supplies smart phones, laptops and electric cars produced by companies such as Apple, Samsung and major car manufacturers. Demand for Cobalt has tripled globally over the last five years and it is estimated that this growth rate will continue in the future, especially as result of the acceleration of the production of electric cars. World Cobalt reserves are estimated at ca. 7,100,000 metric tons. The Democratic Republic of Congo (DRC) currently produces $63 \%$ of the world's Cobalt need. By 2030, global demand of Co could be 47 times higher than in 2017, Bloomberg New Energy Finance estimates [7].

Although EVs are presented as super-clean vehicles, consumers should also consider the following:

1. How is electricity charging the battery of the electric cars produced? Is it hydropower (the happy case of Norway) or produced in coal-fired power plants (see air pollution in northeastern China due to coal-fired power plants);

2. The impact on the environment caused by the exploitation of Cobalt mines in the Democratic Republic of Congo (causing dust emissions, wastewater.) (Figure 5);

3. Child labor used in the exploitation of artisanal cobalt deposits in the Democratic Republic of Congo, a situation unanimously condemned in all economic forums;

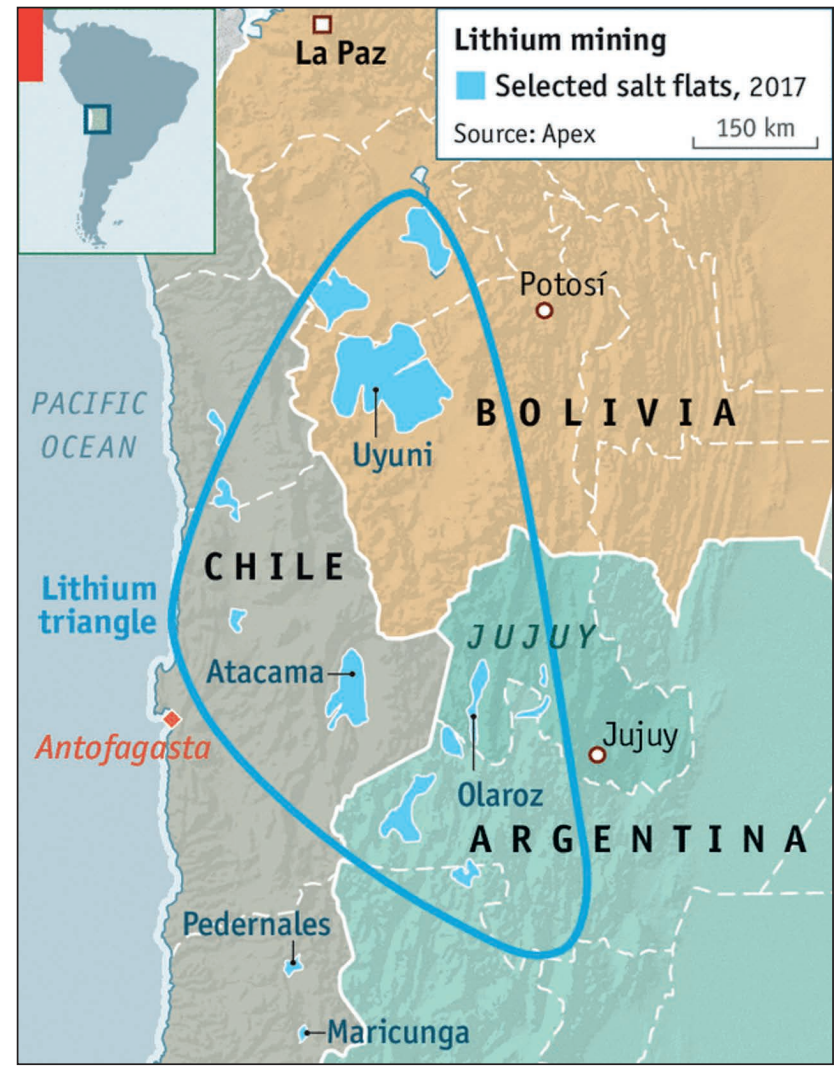

Figure 2. The Lithium triangle [5]

4. Environmental risks arising in Latin America in the Lithium triangle (water shortage, toxic discharges from Lithium exploitation, etc.);

5. Pollution caused by the exploitation of Nickel in Russia (Figure 6).

The battery is a consumable item with a limited service life. The logical question here is what will be done with tons and tons of used batteries after they have served their 


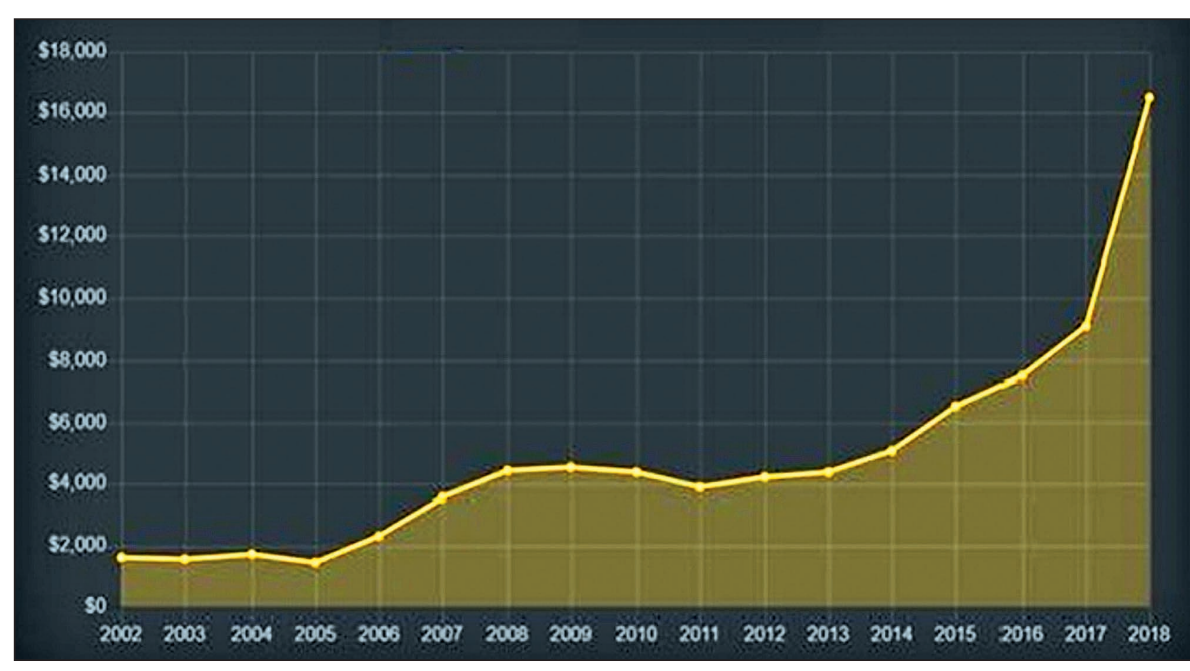

Figure 3. The price evolution of Lithium, 2002-2018 (metric ton) [6]

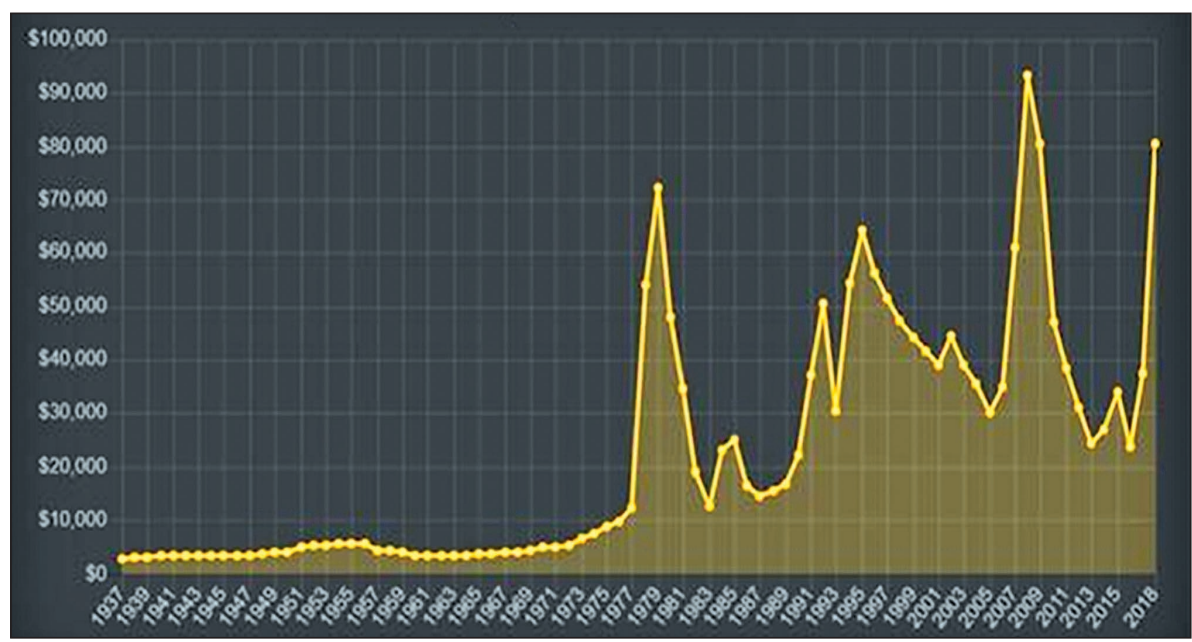

Figure 4. The price evolution of Cobalt, 1937-2018 (metric ton) [8] support many other applications (in households as energy sources). Thus, their life cycle could be extended to about 20 years.

Battery recycling is the second solution. As mentioned before, the Li-ion battery is made from expensive and rare materials. Obviously, battery recycling is a complex and expensive process. For example, in order to recover 1 ton of Lithium, about 30 tons of batteries need to be recycled. But, in order to extract a ton of raw Lithium from a mine, 1.375 tons of ore must be excavated and processed.

\section{Problems IN RECYCLING LI-ION BATTERIES}

Li-ion batteries present several unresolved problems: due to the electrolyte, under certain conditions, they can ignite. In this field, research is being carried out assiduously, but the problem is not fully solved. Traditionally, the electrolyte is an organic solvent. In conditions of intense use it initially produces heat (thermal leaks) and can even ignite. Even used batteries, if not completely discharged, degraded (broken) can cause fires in the trash pit, fires that are very difficult to extinguish (Figure 7).

Until solid, non-flammable electrolytes are discovered, the purposes. According to a Financial Times estimate, 11 million tons of used Li-ion batteries will be on the market by 2025.

\section{WHAT CAN BE DONE?}

EV batteries have an estimated life cycle of up to 10 years; when the battery capacity drops below $70 \%$ they are no longer suitable for an EV, but they are powerful enough to

\section{Figure 5. Cobalt mining in DR of Congo (courtesy of} foreignbrief.com) [9]
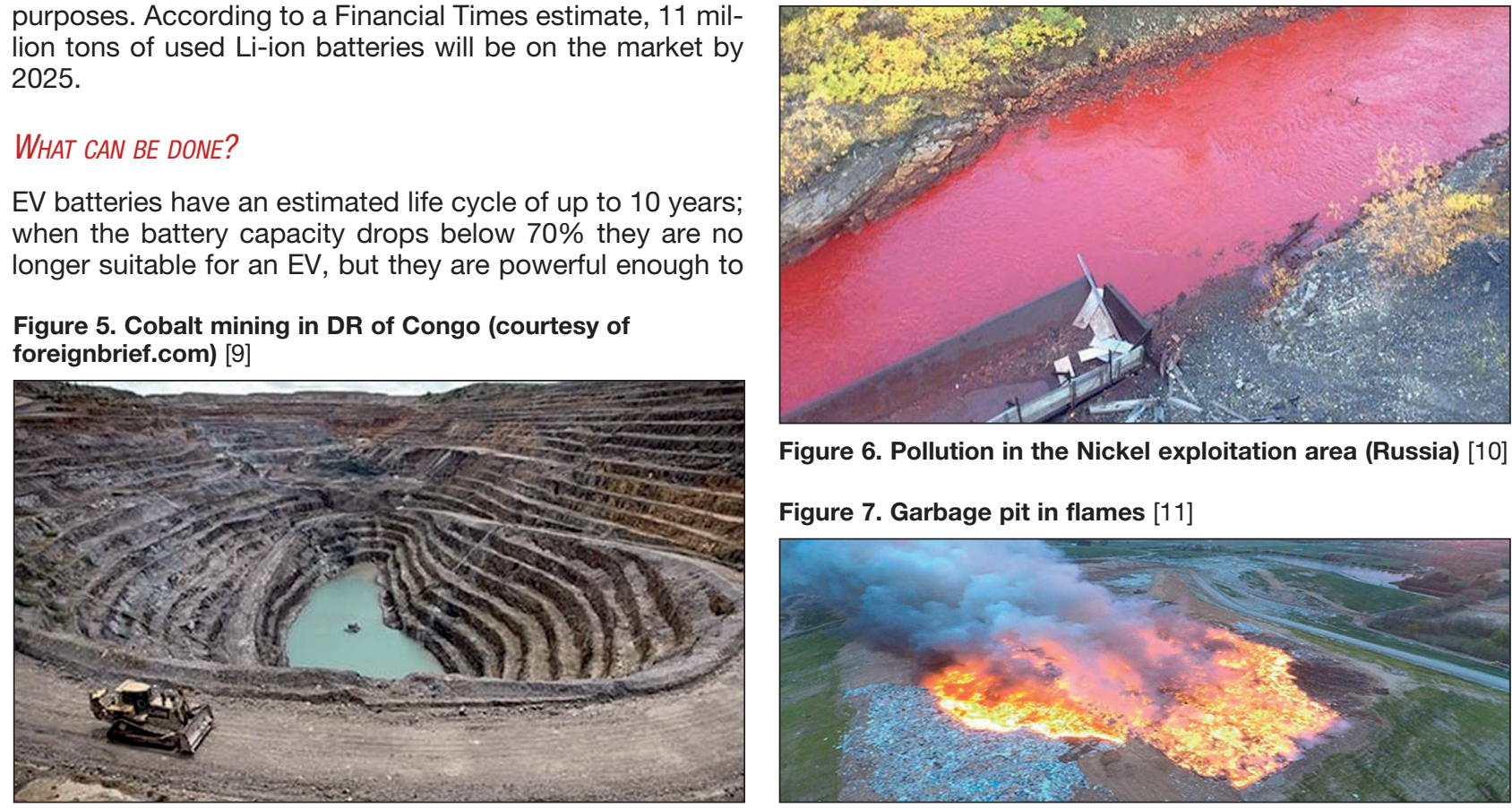

Figure 6. Pollution in the Nickel exploitation area (Russia) [10]

Figure 7. Garbage pit in flames [11]

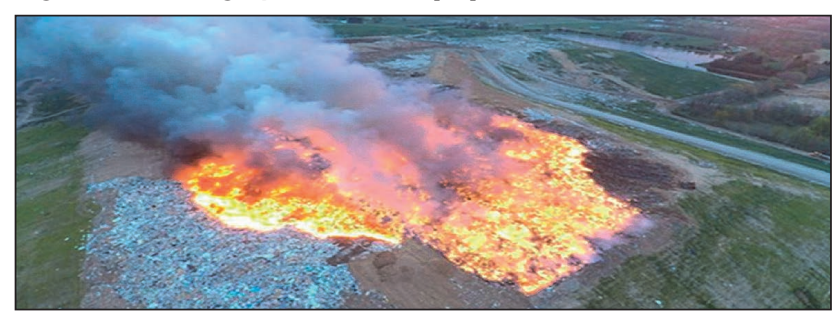




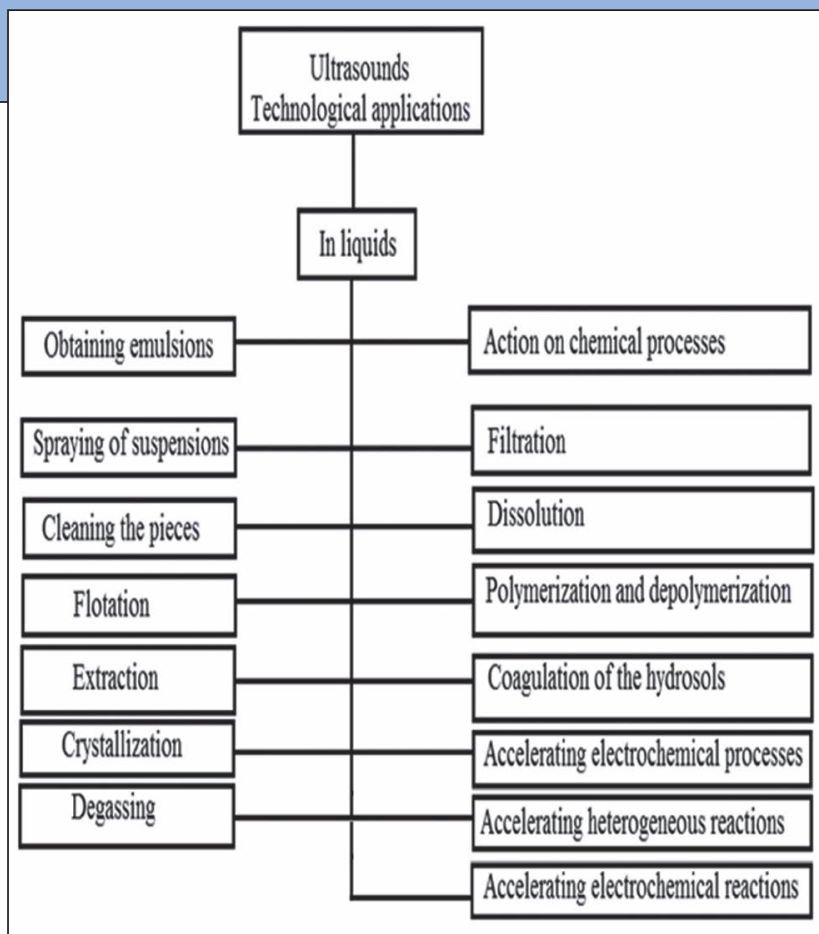

Figure 8 . The technological applications of ultrasounds in liquid medium [13]

legislation must be changed to collect Li-ion batteries for the purpose of complete discharge and then for their proper storage for the purpose of recycling the useful metals contained.

\section{MATERIALS AND METHODS}

\section{RESEARCH TO RECOVER CO FROM SPENT LI-ION BATTERIES}

Our experiments aimed at establishing a recovery technology of the cathode (Co-containing) paste from the Aluminum (Al) foil. We used ultrasounds in a weak acid environment [12]. UItrasounds have found numerous technological applications due to their specific properties: short wavelength, high particle acceleration (can reach values higher than $10^{5}$ times the acceleration of gravity), and the possibility of targeting and focusing of acoustic energy in inaccessible areas. Figure 8 presents some of the technological applications [13] of ultrasounds in liquid medium.

The spent Lithium-ion batteries used in this study come from mobile phones and were dismantled manually in order to extract the cathode material [14] The spent LIBs were discharged completely in a salt solution for $1 \mathrm{~h}$ and dismantled manually to separate the cathode materials coated on the Aluminum foil.

The Al-foil was cut into small pieces initially (kept intact for
Figure 9. The separation process of the cathode material [15]

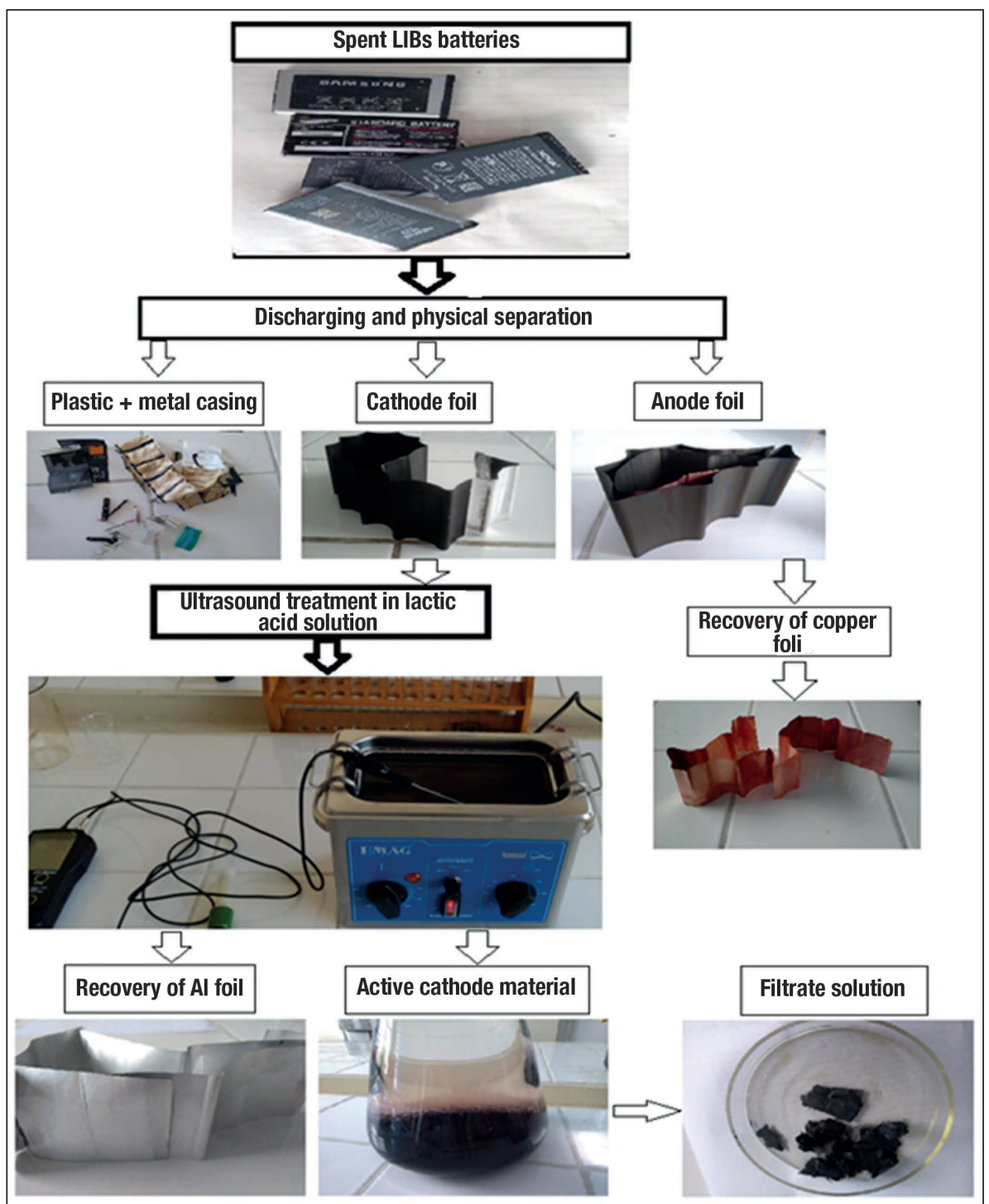

final experiments), immersed in acidic solution (lactic acid $\mathrm{C}_{3} \mathrm{H}_{6} \mathrm{O}=$ ) and subjected to ultrasonic cleaning. Once all the active cathode material was detached from the Aluminum foil, it was filtered and washed with alcohol, and filtered again. Figure 9 illustrates the steps of the recovery process.

The ultrasonic cleaning installations consist of the following elements: the casing, the washbasin, and the transducer. The ultrasonic cleaning machine (Emmi12-HC) used has the following technical specifications: housing - stainless steel, cleaning frequency $=45 \mathrm{kHz}$; cleaning time $=$ $1-60 \mathrm{~min}$; volume $=1.2 \mathrm{l}$; heating temperature $=20-80^{\circ} \mathrm{C}$; bath dimension $200 \times 100 \times 65 \mathrm{~mm}$; ultrasonic power = $50 / 75 / 100 \mathrm{~W}$. The main advantages of the ultrasonic cleaning process are reduced working time, low cost of the whole process, high productivity and lack of superficial microfiches [16].

The ultrasonic cleaning process is based on the phenomenon of ultrasonic cavitations [16], which can be seen in Figure10. This process can be explained as follows: changes in pressure and fluid breakage favor the formation of cavitations bubbles, which once penetrated into the pores of the adhering layer increase in size and produce a gradual detachment of this layer. 


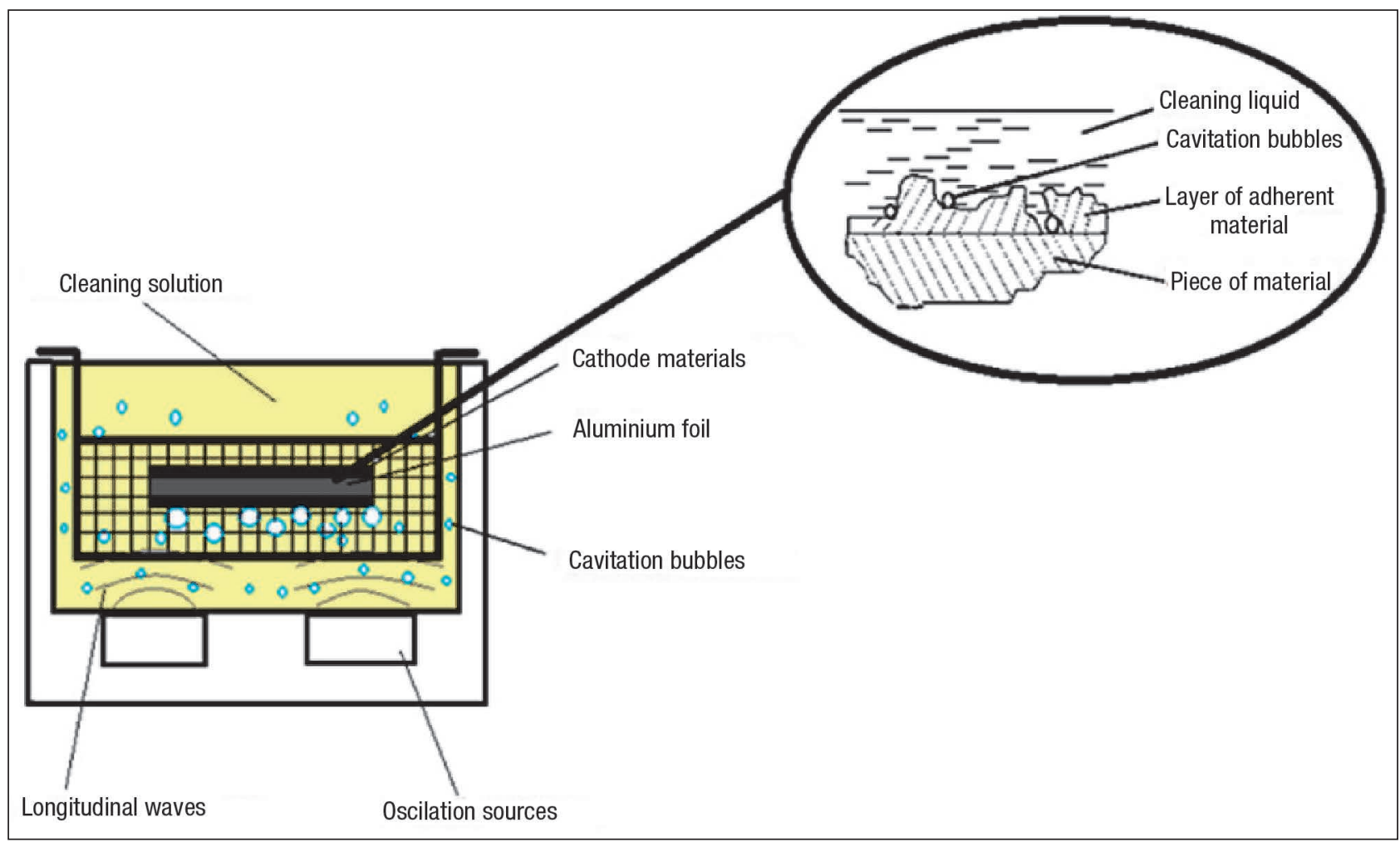

Figure 10. Visualization of cavitations effect on cathode foils [15]

The samples were analyzed by Scanning Electron Microscopy using a Quanta Inspect F50, with a Field Emission Gun (FEG) with a resolution of $1.2 \mathrm{~nm}$, and an EDX analyzer having a resolution of $133 \mathrm{eV}$ at MnK.

\section{RESULTS AND DISCUSSIONS}

The ultrasonic process (in acidic environment) is very complex, and there are many factors that can influence the efficiency of the process of stripping / detaching the active paste from the Aluminum foil (cathode). In all tests the ultrasound frequency was kept at $45 \mathrm{~Hz}$ and the concentration of oxygenated water at $5 \%$. The temperature inside the ultrasonic bath represents the controllable variable and was increased from 20 to $50{ }^{\circ} \mathrm{C}$.

Several attempts were made in order to obtain the proper parameters for a maximum recovery potential. Since the amount of foils used for experimentation was limited, the foils were cut into equal pieces (12 pieces), being used for each preliminary experiment. Once the optimal parameters of the ultrasonic separation process had been established, whole foils were used to separate the active paste.

The first set of experiments took place at different lactic acid concentrations. Figure 11 shows the evolution of separation efficiency at different concentrations (1.34...1.7 M) of lactic acid.

Figure 11. Influence of pH on separation efficiency

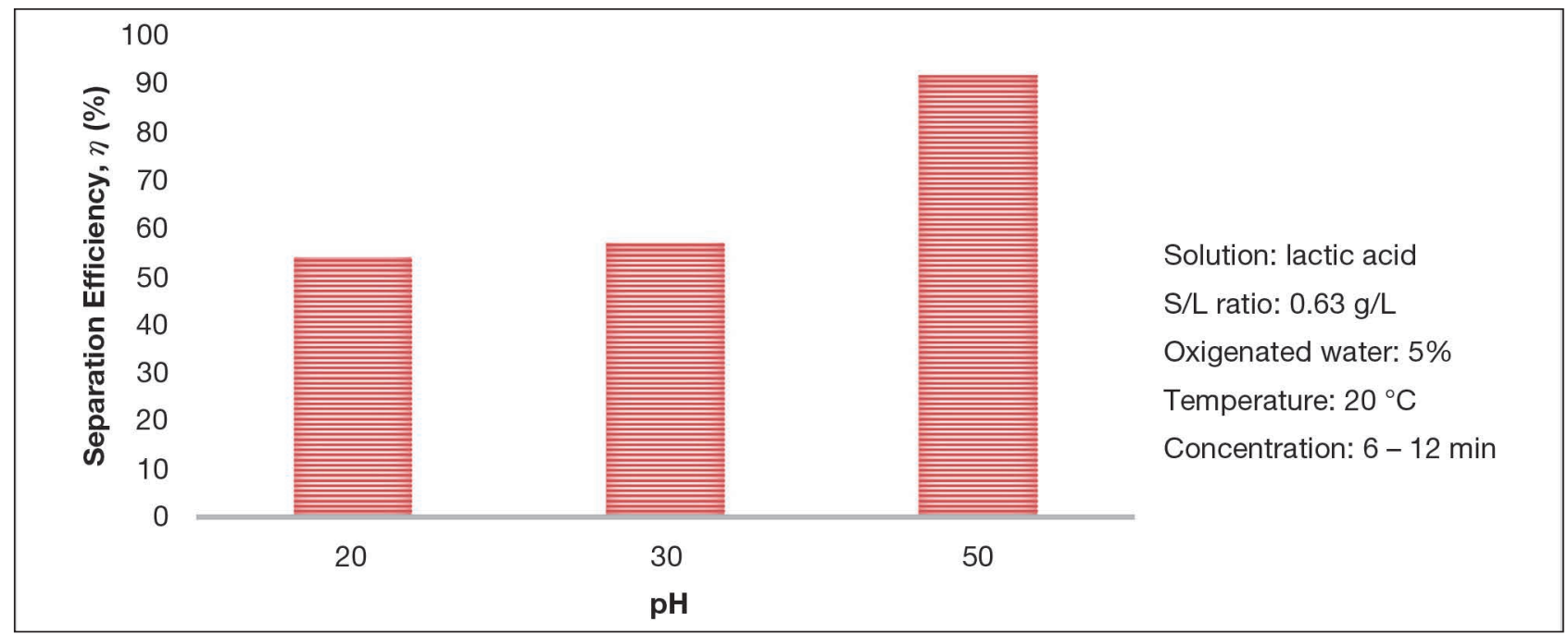




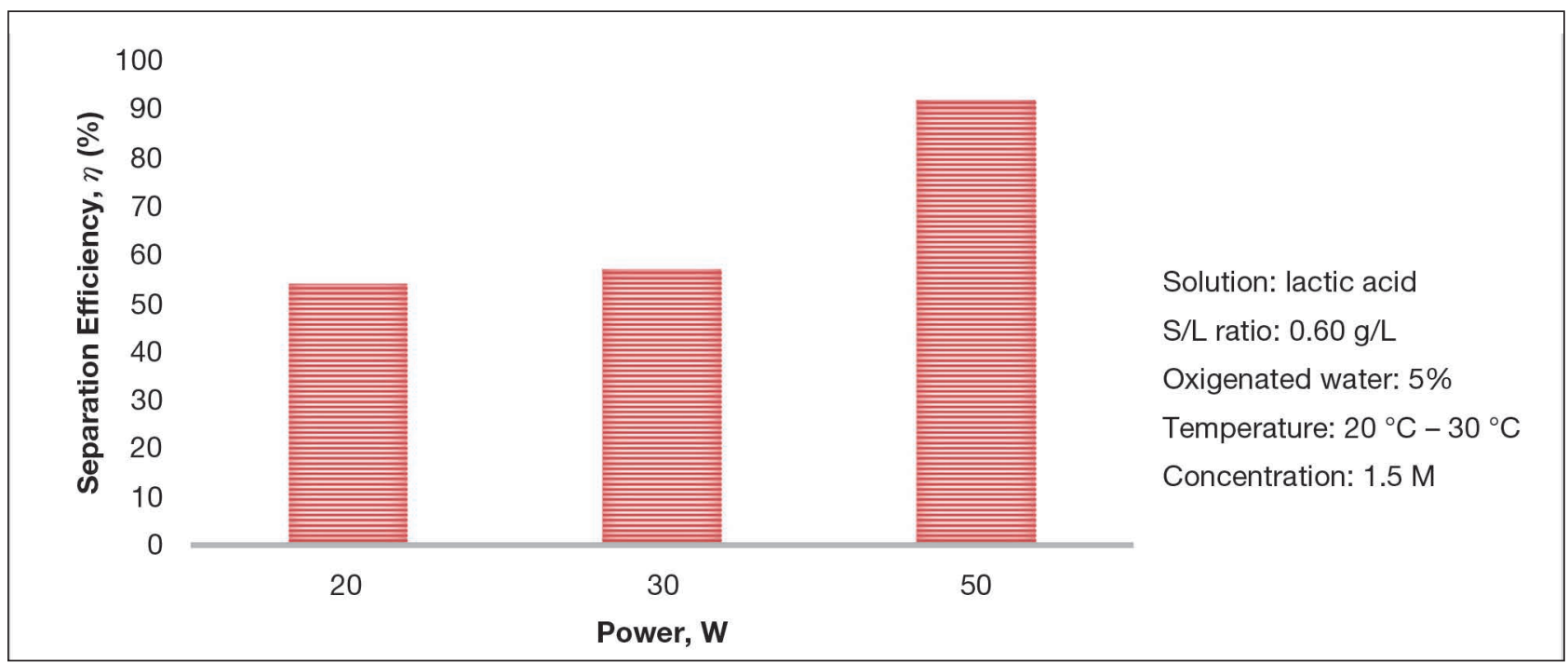

Figure 12. Influence of ultrasonic power on the separation efficiency

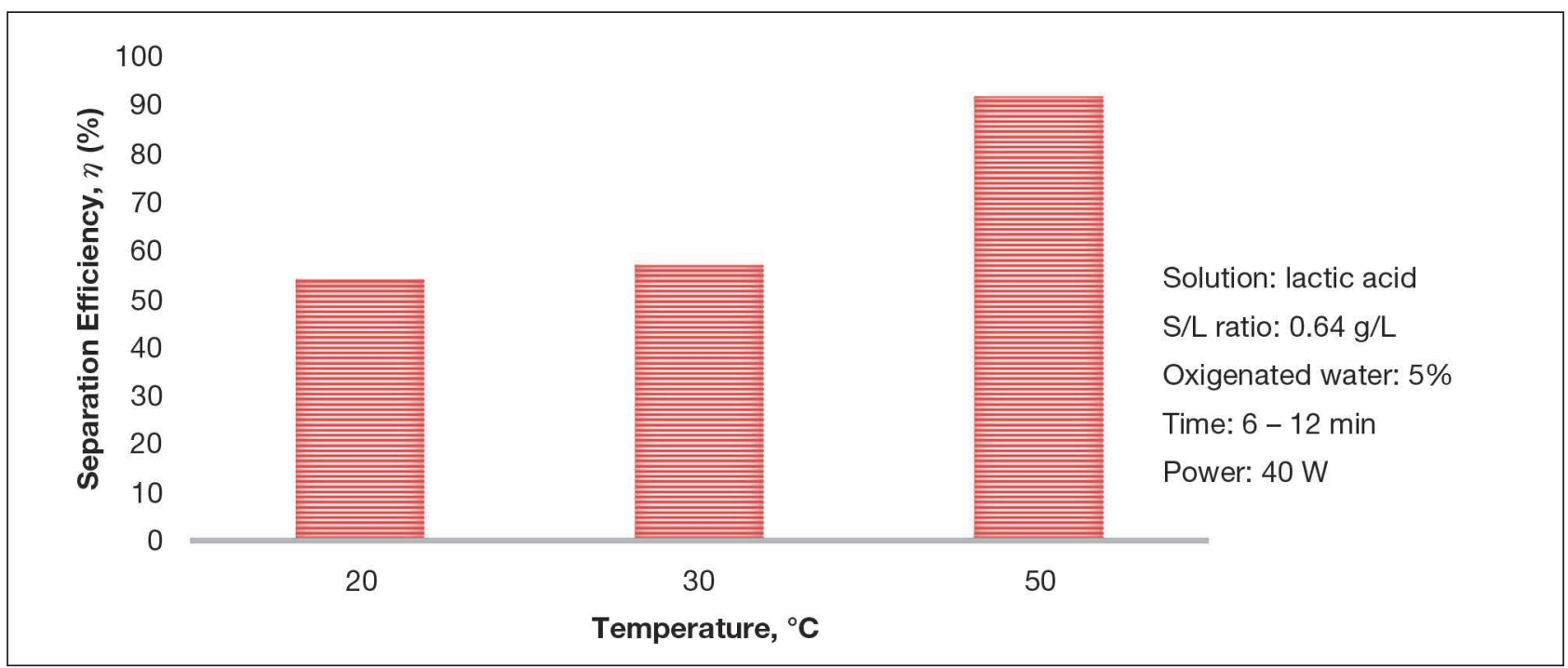

Figure 13. Influence of temperature on separation efficiency

Separation efficiency was calculated with the following equation:

$$
\eta=\frac{m_{i}-m_{f}}{m_{i}} \cdot 100
$$

$\eta$ - separation efficiency; $m_{i}$ - initial weight of cathode; $m_{f}$ - final weight of cathode piece.

The second set of experiments took place at different ultrasonic power levels. Figure 12 illustrates the effective removal of active cathode paste from Al film at different ultrasonic power levels.

The third set of experiments took place at different temperatures. Figure 13 illustrates the evolution of the separation time during the recovery process of active paste at different temperatures.

It can be observed that lactic acid concentration and the power and temperature of the ultrasonic bath play a major role in the separation of the cathode material. The proper concentration for maximum efficiency (reduced ultrasonic time) was reached at a concentration of $1.7 \mathrm{M}$ for lactic acid. The data shows that the ultrasonic power influences recovery time; a higher ultrasonic power applied decreases the process efficiency (increases cleaning time). A temperature around $50{ }^{\circ} \mathrm{C}$ greatly shortens the recovery time of the active paste on the cathode sheet.

The SEM images of the samples after separation are presented in Figure 14.

\section{Conclusions}

- In this paper an environmentally friendly way for the recovery of active cathode material from spent Li-ion batteries was investigated. The ultrasound technology has the advantages of being easy to use, working at different temperatures without the need for additional heat, and low working times.

- The solution used, i.e. lactic acid $-\mathrm{C}_{3} \mathrm{H}_{6} \mathrm{O}_{3}$, was used to completely detach the cathode material from Al-foil without degrading the material. The results obtained have shown that the technique presents good results at the established parameters. The concentration of oxygenated water has no significant influence on the process. 

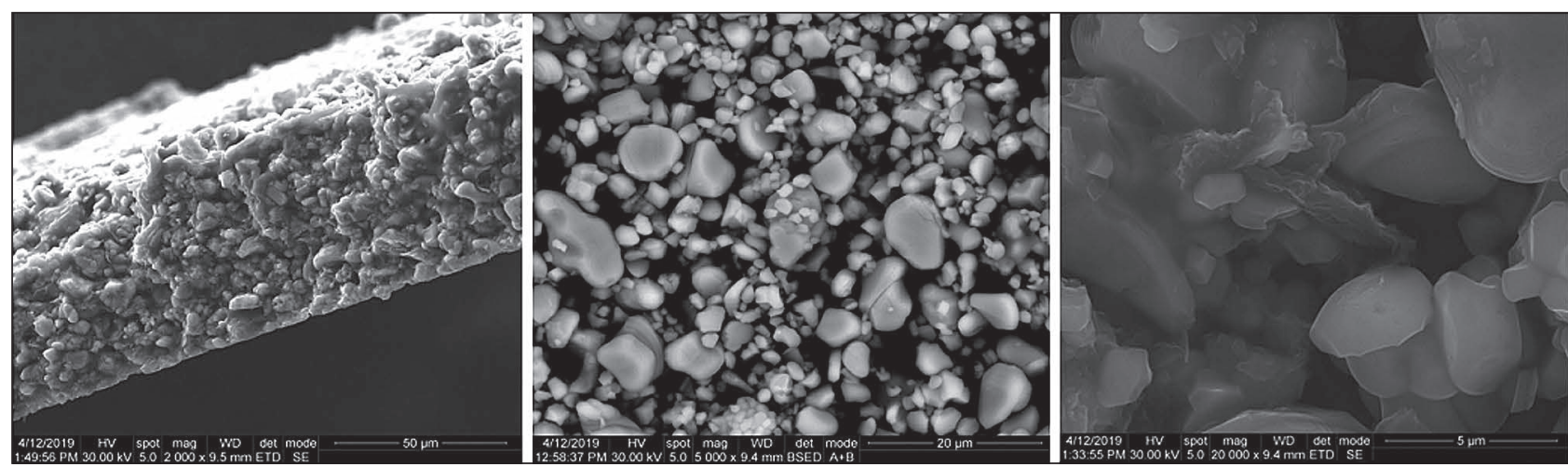

Figure 14. SEM images of the foil after separation $(\times 500 ; \times 2000$ and $\times 10000)$

- The optimal parameters for the ultrasonic process and obtaining a high separation efficiency of the active paste were the following:

- Concentration of lactic acid solution: $1.7 \mathrm{M}$;

- Concentration of oxygenated water: $5 \%$;

- Temperature of the ultrasonic bath: $50{ }^{\circ} \mathrm{C}$;

- The power of ultrasonic bath: $80 \mathrm{~W}$;

- Time range of recovery between 1.5 to 2.5 minutes.

- Once the optimal parameters had been established, the process was tested using an entire cathode foil. The result was a maximum separation efficiency of $\eta=88.08 \%$.

- In the future, we propose to further process the cathode powder of $\mathrm{LiCoO}_{2}$ and clean PVDF (polyvinylidene fluoride) material using a hydrometallurgical method in order not to degrade the active material.

\section{REFERENCES}

[1] Chiaki Iwakura, Yuko Fukumoto, Hiroshi Inoue, Syunpei Ohashi, Satoshi Kobayashi, Hiroshi Tada and Masaaki Abe. 1997."Electrochemical characterization of various metal foils as a current collector of positive electrode for rechargeable lithium batteries." Journal of Power Sources 68, no. 2: 301-303. doi:/10.1016/S0378-7753(97)02538-X.

[2] Cristina-Madalina Toma, Valeriu-Gabriel Ghica, Mihai Buzatu, Mircea-lonut Petrescu, Eugenia Vasile and Gheorghe lacob. 2017. "A Recovery Process of Active Cathode Paste from Spent Li-Ion Batteries" IOP Conf. Series: Materials Science and Engineering 209, no. 012034: 1-8.

doi:10.1088/1757-899X/209/1/012034

[3] Eco Warrior. 2018. "Electric Cars: How Much They Really Cost (the Environment)." Accessed November 1, 2019. https://ecowarriorprincess.net/2018/09/ electric-cars-how-much-they-really-cost-the-environment-3/.

[4] Jato. 2019. "Global car market remains stable during 2018, as continuous demand for SUVs offsets decline in sales of Compact cars and MPVs." Accessed November 1, 2019. https://www.jato.com/ global-car-market-remains-stable-during-2018-ascontinuous-demand-for-suvs-offsets-decline-insales-of-compact-cars-and-mpvs/.

[5] The Economist. 2017. "A battle for supremacy in the lithium triangle." Accessed November 1, 2019. https://www.economist.com/the- americas/2017/06/15/a-battle-for-supremacy-in-thelithium-triangle.

[6] Joyce A. Ober. 2007. "Lithium". United States Geological Survey. pp. 77-78. Accessed November 1, 2019. http://minerals.usgs.gov/minerals/pubs/ commodity/lithium/450798.pdf

[7] Wikipedia. 2019. "Cobalt." Accessed November 1, 2019. https://en.wikipedia.org/wiki/Cobalt.

[8] Infomines. 2019. "Cobalt Prices and Cobalt Price Charts." Accessed November 1, 2019. http://www. infomine.com/investment/metal-prices/cobalt/.

[9] Foreign Brief. 2019. "The cobalt boom: recharging trouble in the Congo." Accessed November 1, 2019. https://www.foreignbrief.com/africa/cobalt-boomrecharging-trouble-congo/

[10] The Verge. 2019. "Why is this Russian river blood red?". Accessed November 1, 2019. https://www. theverge.com/2016/9/7/12840374/norilsk-red-riverrussia-chemical-leak-mine-waste

[11] Imgur. 2019. "Elkhart landfill fire." Accessed November 1, 2019. https://imgur.com/gallery/02O23.

[12] Gabriel-Valeriu Ghica, Cristina-Madalina Toma, Mihai Buzatu, Mircea-lonut Petrescu, Gheorghe lacob, Iulian-Vasile Antoniac, Eugenia Vasile, and Francesco Veglio, 2017. "Recovery of active cathode material containing $\mathrm{Co}$ and $\mathrm{Li}$ from waste $\mathrm{Li}$-ion batteries" U.P.B. Sci. Bull., Series B. 79, no. 3: 75-86.

[13] Ioan Anton. 1984. Cavitation (in Romanian - Cavitatia), Bucharest: Academia Publishing House.

[14] Ancuta Mihaela Turcu, Valeriu Gabriel Ghica, Francesco Veglio, Mihai Buzatu, Mircea-lonut Petrescu, Gheorghe lacob, lonela Bîrloagă. 2018. "Catalytic paste solubilization researches regarding the cobalt recovery from used $\mathrm{Li}$-ion batteries ANOVA application". U.P.B. Sci. Bull., Series B 80 , no. 3: 183-194.

[15] Ionuț Bratosin, Cristina-Mădălina Toma, Eugeniu Vasile, Valeriu-Gabriel Ghica, Mihai Buzatu, Mircea-lonuț Petrescu, Gheorghe lacob, Tunde-Anna Kovács, 2019, "Recovery of LiCoO2 compound from cathodic paste of waste LIBs, by ultrasonography in lactic acid solution", IOP Conf. Series: Materials Science and Engineering, 572, no. 012053, DOI information: doi:10.1088/1757-899X/572/1/012053.

[16] Niculae-Ion Marinescu. 1986. Ultrasound processing (in Romanian - Prelucrari cu ultrasunete), Bucharest: Technical Publishing House. 